\title{
Gradients in coral reef fish density and size across the Barbados Marine Reserve boundary: effects of reserve protection and habitat characteristics
}

\author{
Matthew R. Chapman, Donald L. Kramer* \\ Department of Biology, McGill University, 1205 Docteur Penfield Ave., Montréal, Quebec H3A 1B1, Canada
}

\begin{abstract}
Reductions in fishing mortality within no-take coral reef marine reserves can produce gradients in the density and size of fishes across reserve boundaries. Such gradients may be affected by other factors, however, including differences in habitat quality between reserve and non-reserve areas and the movement of fish across reserve boundaries. To examine the effects of protection from fishing mortality and of habitat quality on an assemblage of exploited reef fishes, we measured the spatial patterns of fish density and size on fringing reefs near the boundary of the Barbados Marine Reserve (Barbados, West Indies) and statistically controlled for habitat correlates of fish density and size. Reserve sites supported a higher total density and size of fishes than non-reserve sites. Most species had a non-significantly higher mean density and size at reserve sites. The density and/or size of many species were correlated with the depth, rugosity, and/or substrate composition of sites. After statistically controlling for the effects of habitat correlates, the difference in total density between reserve and non-reserve sites remained significant, and the mean density and size of most species remained nonsignificantly higher at reserve sites. Neither the mobility of species nor their vulnerability to capture by Antillean fish traps was correlated with their relative difference in density or size between reserve and non-reserve sites. Spearfishing target species had a significantly higher relative difference in size between reserve and non-reserve sites than non-target species. Protection from fishing mortality and higher habitat quality appear to contribute to the increased density and size of fishes on study reefs in the Barbados Marine Reserve, and this difference is not compromised by emigration from the reserve.
\end{abstract}

KEY WORDS: Marine protected area $\cdot$ Harvest refugia $\cdot$ Mobility $\cdot$ Spillover

\section{INTRODUCTION}

Reserves that prohibit the exploitation of marine organisms have been established in a variety of marine habitats for several purposes, including the separation of conflicting uses of marine resources and the provision of control areas for investigations of the effects of fishing (Rowley 1994, Bohnsack \& Ault 1996). Because such 'no-take' marine reserves can support a greater density, size, and diversity of fishes within their boundaries than exploited areas (Plan Development Team

•E-mail: don_kramer@maclan.mcgill.ca
[PDT] 1990, Roberts \& Polunin 1991, Dugan \& Davis 1993), they also provide a valuable tool for the conservation of overexploited fishes. Moreover, increases in fish density and size within no-take reserves also have the potential to enhance the yield of neighbouring fisheries, despite the reduction in fished area due to the establishment of the reserve (e.g. PDT 1990, DeMartini 1993, Sladek Nowlis \& Roberts 1997).

Increases in fish density and size due to reserve protection can result in the enhancement of fishery yields through 2 mechanisms: the export of larvae and the emigration of post-settlement individuals. Increases in spawning stock biomass within a reserve may result in enhanced larval production and in- 
creased settlement within and outside the reserve. Reserves can thereby address recruitment overfishing over the spatial scale of larval dispersal (PDT 1990, Sladek Nowlis \& Roberts 1997, Bohnsack 1996). If post-settlement fishes move across reserve boundaries, increases in fish density within a reserve will result in net emigration to nearby fished areas as a result of random movements and density-dependent habitat selection (Roberts \& Polunin 1991, DeMartini 1993, Rakitin \& Kramer 1996, Kramer \& Chapman in press). Net emigration ('spillover') of reef fish from no-take marine reserves can reduce the effects of growth overfishing in neighbouring fisheries (Russ 1985, PDT 1990, Russ et al. 1992).

Several studies have quantified the effects of reserve protection on fish communities and examined the potential of reserves to provide conservation and fisheries benefits in coral reef ecosystems (reviews by PDT 1990, Roberts \& Polunin 1991, Rowley 1994). Ideally, quantification of the effect of reserve protection on reef fish communities should incorporate controls for both spatial and temporal variation in fish distribution (Russ \& Alcala 1996); however, information on fish densities before reserve implementation is often not available. Thus, the most common measure of the effect of reserve protection of reef fish communities is the difference in density between sites in a reserve and ecologically similar sites in nearby fished areas (e.g. Russ 1985, Polunin \& Roberts 1993). This measure may be confounded by spatial variation in other factors affecting fish distribution, such as differences in habitat quality between the 2 areas (e.g. Polunin \& Roberts 1993, Grigg 1994). The abundance of many reef fishes is correlated with variation in characteristics of the reef habitat, such as substrate topographic complexity (e.g. Luckhurst \& Luckhurst 1978) and coral cover (e.g. Bell \& Galzin 1984). Moreover, reserve sites are often chosen for their high initial habitat quality and fish abundance (e.g. Russ 1985). Few studies (Grigg 1994, Jennings et al. 1996) have statistically examined potential habitat correlates of fish density and size when assessing the effect of reserve protection on coral reef fish distribution.

Net emigration of fish across reserve boundaries may slow the rate of increase of fish density within the reserve and limit the maximum difference in fish density between reserve and non-reserve areas. If some reef fish emigrate from a reserve, the spatial pattern of fish density across reserve boundaries will vary among species according to their movement behaviour. Mobile species - i.e those with large home ranges and those which relocate home ranges frequently-are more likely to cross reserve boundaries than sedentary species. If movement across reserve boundaries exposes mobile fish in the reserve to fishing mortality in

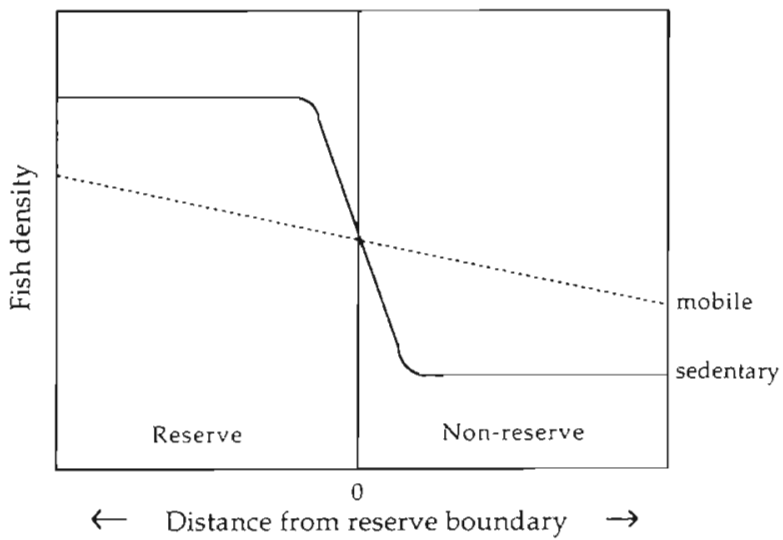

Fig. 1. The mobility of exploited species should influence their distribution relative to the boundaries of a no-take marine reserve. Modified from Rakitin \& Kramer (1996)

adjacent fished areas, mobile species should exhibit a gradual change in density across the reserve boundary, whereas sedentary species should exhibit an abrupt change in density at the reserve boundary (Rakitin \& Kramer 1996). Near the reserve boundary, this should result in a greater difference in density between the reserve and the fished area for less mobile species (Fig. 1).

The effect of reserve protection on the density and size of fishes within and outside reserves will also vary among species according to their vulnerability to the fishery. Species and size classes that are more vulnerable to local fishing techniques are expected to show a greater increase in density as a result of the prohibition of fishing within the reserve (Rakitin \& Kramer 1996).

In Barbados, West Indies, Rakitin \& Kramer (1996) found a gradual decrease in the catch rate of coral reef fish with increasing distance from the centre of the notake Barbados Marine Reserve (BMR), rather than a sudden change in catch rate at the reserve boundary. They hypothesized that this gradient was due to net movement of fishes from the reserve to fished nonreserve (NR) reefs. The gradient was not evident in visual censuses or in the catch rate of individual species, however. Rakitin \& Kramer (1996) hypothesized that, if fish movements were causing this gradual decline, the difference in density between the BMR and NR should be higher for less mobile species, but their preliminary test (in which species were classified as either 'mobile' or 'sedentary' based on literature reports) did not support this hypothesis. Although there were non-significant trends towards higher rugosity, higher live coral cover, and lower sand cover at BMR study sites, Rakitin \& Kramer (1996) did not examine the effects of habitat variables on fish density or catch rate. The observed spatial gradient in catch 
rate may have been due to spatial gradients in factors which affect density and catch rate, such as habitat characteristics (Jennings et al. 1996, Robichaud 1996, Robichaud et al. 1999).

In order to determine the effects of reserve protection and of habitat characteristics on the distribution of fish inside and outside the BMR, this study examines the spatial patterns of fish density and size at sites near the BMR-NR boundary and tests for habitat correlates of fish density and size at these sites. We compare fish density and size between BMR and NR sites to test the hypothesis that there is a gradient in the density and size of fishes across the northern boundary of the BMR. We statistically control for the effects of habitat correlates of the density and size of reef fish species to test the hypothesis that differences in density and size are due to reserve protection rather than measured habitat differences. We also examine the effects of vulnerability to Antillean fish traps and spearfishing on the difference in fish density and size between BMR and NR sites to test the hypothesis that species more vulnerable to fishing mortality will show greater differences in density and size between the BMR and NR. Finally, we use data from a mark-recapture study of reef fish movements at the same study sites (Chapman 1997. Chapman \& Kramer in press) to examine the importance of post-settlement fish movements to the distribution of fish inside and outside the BMR. Specifically, we test the hypothesis that less mobile species will exhibit a greater difference in density and size between BMR and NR sites.

\section{METHODS}

Study sites. This study took place on the west (leeward) coast of Barbados between November 1995 and June 1996. Along this coast, fringing coral reefs extend up to $300 \mathrm{~m}$ from shore, to a depth of about $10 \mathrm{~m}$. The physiography of the coast has been described by Stearn et al. (1977) and the zonation of fringing reefs by Lewis (1960) and Rakitin (1994). The study sites were located on 4 fringing reefs along the west coast, 2 reefs inside the BMR (South Bellairs and North Bellairs reefs) and 2 reefs in the adjacent NR (Heron Bay and Bachelor Hall reefs). The study reefs are separated by extensive (20-150 $\mathrm{m}$ and $150-300 \mathrm{~m}$ ) patches of sand and rubble and small patches of rocky reef $\left(<10 \mathrm{~m}^{2}\right)$, except the 2 reserve reefs, which are almost contiguous, separated by a sand channel as narrow as $10 \mathrm{~m}$ across (Fig. 2).

The BMR consists of $2.2 \mathrm{~km}$ of protected waters along the central west coast of Barbados and includes 5 fringing reefs. The reserve extends seaward 500 to $750 \mathrm{~m}$ to include portions of an offshore bank reef sys-

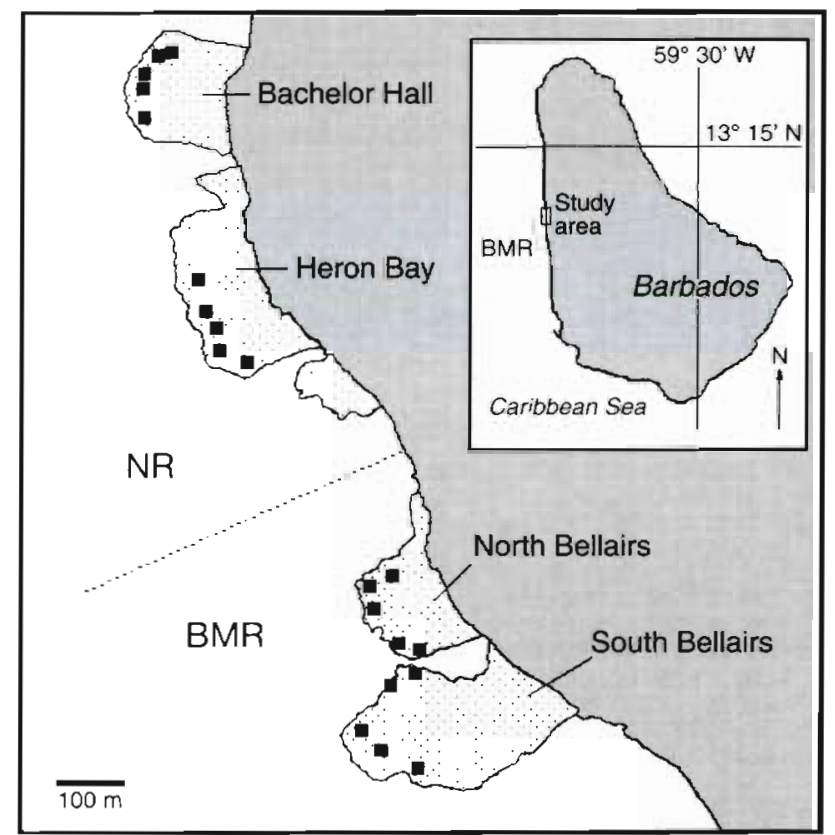

Fig. 2. Study sites ( $\boldsymbol{\square})$ within the 4 study reefs (stippled areas). Dashed line: boundary between the Barbados Marine Reserve, West Indies (BMR), and the NR (non-reserve) area. Inset: map of Barbados showing the lacation of the BMR and the study area

tem. The BMR was established in 1981 and legislation prohibits the dynamiting of reefs and the harvesting of corals, invertebrates and fishes, with the exception of cast-netting for clupeids (St. Hill 1987); however, illegal fishing, including spearfishing and line-fishing from boats and shore, occurs to some extent (Rakitin 1994, pers. obs.).

Fringing reefs in the adjacent NR experience light exploitation from spearfishing, line-fishing, and from an artisanal trap fishery (Miller \& Hunte 1987, Mahon \& Drayton 1990, Rakitin 1994, pers. obs.). The principal gear-type of the Barbados demersal reef fishery is the Antillean fish trap (Miller \& Hunte 1987), described in detail by Munro et al. (1971). In Barbados, traps are built of wire mesh supported by a wooden frame with a single entrance funnel. Traps are set baited or unbaited on reef, rubble or sandy substrates for several days before hauling and emptying. Mahon \& Drayton (1990) estimated there were approximately 200 fulland part-time trap fishers on the West and South coasts of Barbados. Based on interviews with local fishers, Rakitin (1994) estimated a total of 40 to 60 traps were set and hauled twice per week on the 7 fringing reefs to the north of the BMR. During the present study, fishing effort outside the northern BMR boundary appeared to be low: we observed occasional spearfishing and line fishing, and only 2 trap sets on the $2 \mathrm{NR}$ 
study reefs over a period of $12 \mathrm{wk}$. Several instances of illegal line-fishing within the BMR were also observed, mainly at night and in the early morning. Although there was widespread fish mortality in this area in 1994, apparently due to a marine bacterium (Alleyne 1996), fish densities had recovered by the time of the study (M. Tupper \& W. Hunte unpubl. data).

Measurements of fish distribution and habitat variables were recorded at 5 sites in the spur-and-groove zone (Lewis 1960) of each of the 4 study reefs (Fig. 2). Sites were $20 \times 20 \mathrm{~m}$ in planar area and included reef, rubble and sandy substrate. Site depth ranged from 1.9 to $8.2 \mathrm{~m}$ (mean $=4.9 \mathrm{~m}$ ). The position of each site was defined as the distance $(\mathrm{m})$ from the site to the northern BMR-NR boundary. Thus, BMR sites have negative values and NR sites have positive values.

Fish density and size. The density and size structure of the fish community on reefs in the BMR and NR were estimated by visual census at all 20 study sites. Using SCUBA, an observer (M.R.C.) performed 3 replicate counts at each site, approximately 1 quarter-lunar period apart. All counts took place between 10:00 and 17:00 h AST (Atlantic Standard Time) between February and June 1996. The order of censuses was selected randomly, with the constraint that an equal number of BMR and NR sites were sampled each quarter-lunar period. Counts were made only on days when traps used to measure trappability and fish movements (see below) were not deployed.

During counts, the observer swam along unmarked transects ( $\sim 3 \mathrm{~m}$ wide) and counted the number of individuals ( $\geq 5 \mathrm{~cm}$ fork length, FL) of 47 species of fish that are caught in commercial Antillean fish traps. To decrease the time required for counts, we excluded the 5 abundant and marginally trappable species of Stegastes (Pomacentridae). These fish rarely enter traps and are probably subject to very low fishing mortality, so their distribution is unlikely to be directly affected by reserve status (Rakitin \& Kramer 1996, Robichaud 1996). Thirty-eight of the 47 listed species were recorded during visual censuses.

To estimate size structure, the FL of all fish was estimated to the nearest $\mathrm{cm}$. The observer was trained by estimating the length of measured sections of PVC pipe along an underwater line, and by estimating the FL of fish in traps immediately prior to hauling the trap and measuring the fish. Training ceased when the absolute value of the estimation error was consistently below $10 \%$ for both PVC pipes and fish in traps. Underwater length estimation of marked fish indicated that estimated FL was highly correlated with FL measured at the time of tagging $\left(r^{2}=0.92, p<0.0001\right.$, mean $[ \pm \mathrm{SD}]$ estimation error $=3.6[ \pm 4.0] \%, \mathrm{n}=896]$. Visual census data were subsequently divided into trappable and non-trappable fish based on estimated FL using body depth-FL relationships from catch data from traps at the study sites (Robichaud 1996). Fish with a predicted body depth greater than the $4.1 \mathrm{~cm}$ maximum mesh aperture of the commercial Antillean fish traps were considered trappable. For 3 species, there were too few captures to estimate the minimum trappable FL so visual census data for these species were excluded from analysis (Priacanthus cruentatus, $\mathrm{BMR}_{\mathrm{n}}$ $=7, \mathrm{NR}_{\mathrm{n}}=3$; Cantherhines macrocerus, $\mathrm{BMR}_{\mathrm{n}}=2$, $\mathrm{NR}_{\mathrm{n}}=0$; Rypticus saponaceus, $\mathrm{BMR}_{\mathrm{n}}=6, \mathrm{NR}_{\mathrm{n}}=11$ ). Therefore, 35 of the 38 species counted were included in analyses of visual census data.

To quantify the difference in fish density between sites in the BMR and the NR, we calculated the relative difference in fish density (RDD) between BMR sites and NR sites for each of 26 species recorded in both the BMR and NR, and for total fish density:

$$
R D D=\left(N_{B M R}-N_{N R}\right) /\left(N_{B M R}+N_{N R}\right)
$$

where $N_{B M R}$ and $N_{N R}$ are the mean densities in the BMR and NR, respectively. This index, selected using Lechowicz's (1982) analysis of the sampling characteristics of indices of food preferences, ranges from -1 to +1 , where positive values indicate higher BMR density, and scales symmetrically about zero. Using this index avoids some of the statistical difficulties of simple ratio measures and difference measures. $\left(\mathrm{N}_{B M R} / \mathrm{N}_{N R}\right.$ approaches infinity as the density outside the reserve approaches zero, and can produce large differences in index values as a result of small absolute differences in density in the fished area. $\mathrm{N}_{\mathrm{BMR}}-\mathrm{N}_{\mathrm{NR}}$ is affected by the absolute density of the species involved.)

The relative difference in size (RDS) between the BMR and NR was calculated for each of 26 species recorded in both the BMR and NR:

$$
\mathrm{RDS}=\left(\mathrm{FL}_{\mathrm{BMR}}-\mathrm{FL}_{\mathrm{NR}}\right) / \mathrm{FL}_{\mathrm{MAX}}
$$

where $F L_{B M R}$ and $F L_{N R}$ are the mean $F L$ of fish in the $B M R$ and $N R$, respectively, and $\mathrm{FL}_{\mathrm{MAX}}$ is the maximum recorded length of the species according to Humann (1994).

Habitat characteristics. To control for potential habitat correlates of fish distribution, we measured abiotic and biotic substrate composition, habitat structural complexity (rugosity), and depth at each of the 20 census sites during June 1996. Habitat variables were measured by performing 3 point-count transects within each census site. For each transect, a $14 \mathrm{~m}$ chain was placed on the substrate parallel to shore at a randomly selected distance from the inshore edge of the census site At $20 \mathrm{~cm}$ intervals $(\mathrm{n}=210$ observations points site $^{-1}$ ), the substrate under the transect chain was classified as reef (solid rock), rubble (loose fragments of rock 1 to $100 \mathrm{~cm}$ long), or sand (loose particulate sediment $\leq 1 \mathrm{~cm}$ maximum dimension). Percent 
reef, percent rubble, and percent sand cover were calculated for each site. Each point was also classified according to biotic characteristics as turf algae $1 \leq 1 \mathrm{~cm}$ height), encrusting coralline algae, fleshy macroalgae, live coral (all species), other live cover (anemones, hydroids, and encrusting and erect gorgonians and sponges), or bare (uncovered reef, rubble or sand) Percent live coral was defined as the number of observation points of live coral at a site divided by the sum of reef and rubble observation points at a site (since live coral was never observed on sand). Percent algal cover was defined as the number of observation points of turf algae and fleshy macroalgae at a site divided by the total number of observation points at a site. Turf algae accounted for $99.3 \%$ of algal cover, and was present on reef, rubble, and sand. Rugosity was defined as the length of the 3 transects ( $42 \mathrm{~m}$ ) divided by sum of the horizontal distances covered by the 3 transects (Luckhurst \& Luckhurst 1978). The minimum and maximum substrate depths were measured along each of the 3 transects. Site depth was defined as the mean of these 6 depth measurements.

If habitat quality differs between reserve and nonreserve areas, collinearity between reserve status and habitat variables could result in spurious significant effects of reserve status on fish density and size (or vice versa). We therefore tested for significant effects of habitat characteristics on the density of each species by performing backwards stepwise multiple regressions (Zar 1996), excluding reserve status from the set of potential independent variables. We subsequently examined residual variation in fish density and size to test for an effect of reserve status. This is a more conservative test of the reserve effect than including reserve status in the multiple regression model, since it may attribute an actual reserve effect to habitat variables, but it will not attribute an effect of habitat variables to reserve protection. Residual variation in density and size at each site was used to calculate the predicted density and size of fishes in the BMR and in the NR after controlling for the effects on species densities of all measured habitat variables.

Fish mobility. Data on fish mobility were obtained from a mark-recapture study of reef fish of trappable size conducted at the same time and sites as this study (Chapman 1997, Chapman \& Kramer in press). The mobility of species was estimated based on the median distance moved by marked fish resighted on the reef (Matthews \& Reavis 1990) and by the maximum distance moved by fish recaptured in traps. Mobility based on resightings was calculated as the median distance between the locations of release and resightings of marked fish for 14 species. Resightings occurred 1 to $182 \mathrm{~d}$ (median $=13 \mathrm{~d}$ ) after the date of release. Individ- uals resighted at the $400 \mathrm{~m}^{2}$ site at which they were tagged and released were considered to have moved 0 $\mathrm{m}$. Since the tag numbers of resighted fish could not be read, the resighting data are based on recognition of unique tag colour codes identifying the site and date of tagging but not individual fish. Mobility based on trap recaptures was calculated for 13 species as the distance between the 2 farthest locations of capture after 5 recaptures of an individual. The time-at-liberty (the number of days between tagging and final recapture of an individual, excluding the number of days individuals spent in traps) for all fish recaptured in traps ranged from 1 to $194 \mathrm{~d}$ (median $=24 \mathrm{~d}$ ). For both trap recapture and resighting data, the frequency distributions of movement distances used to generate mobility estimates were weighted by correction factors to account for bias due to the spatial distribution of recapture effort (Chapman 1997, Chapman \& Kramer in press).

Vulnerability to fishing mortality. The vulnerability of fish species to Antillean fish traps was estimated by fishing at the NR study sites. A trap was placed at the centre of each of the ten $400 \mathrm{~m}^{2}$ visual census sites in the NR on sand or rubble substrate 0 to $2 \mathrm{~m}$ from a reef spur. Traps were deployed for $4 \mathrm{~d}$, after which the number of fish of each species in the trap was recorded. Traps were subsequently opened underwater (or hauled the following day) and all fish released. From 4 to 11 trap sets were made at each of the $10 \mathrm{NR}$ study sites (total $n=81$ ). Trappability is defined as the ratio of catch rate (mean number of fish caught per trap set at each site, summed for all 10 NR sites) to fish density (mean number of fish counted per visual census at each site, summed for all 10 NR sites). Trappability was estimated for 24 species caught in traps and counted in visual censuses in the NR.

Epinephelus cruentatus, E. fulvus, Kyphosus sectatrix, Lutjanus mahogani, Scarus vetula and Sparisoma viride are commonly captured by spearfishers on fringing reefs on the west coast of Barbados (Rakitin 1994, pers. obs.), and were classified as spearfishing target species.

Data analysis. Fish density, size, and habitat data were tested for normality (Shapiro-Wilks test; Zar 1996), and were $\log _{10}$-transformed if significantly nonnormal. Where transformation did not result in normality, non-parametric tests were used. Regression analyses were tested for normality of residuals using the Shapiro-Wilks test and for excessive leverage $(D>0.5)$ using Cook's test. Where the same hypothesis was tested for several species, $\alpha$ was adjusted using the sequential Bonferroni procedure (Rice 1989); adjusted significance levels are given. Multiple regressions of habitat correlates of fish density and size were performed using the backwards stepwise procedure (Zar 1996) of JMP (SAS Institute). Multiple regression mod- 
els were considered significant for $p<0.05$; however, adjusted significance levels (sequential Bonferroni procedure) are provided.

In a mixed-model nested ANOVA of $\log _{10}$-transformed fish density versus reserve and versus sitewithin-reserve, there was no significant effect of sitewithin-reserve $(p>0.30)$. Thus, we pooled the error variance and the site-within-reserve variance (Zar 1996), and used a simple 1-way ANOVA of density versus reserve status to test for differences between reserve and non-reserve density.

\section{RESULTS}

\section{Fish density and size}

The total density of trappable fish in visual censuses was significantly higher at sites in the BMR than at sites in the NR (ANOVA, $F=10.84, \mathrm{df}=1,18, \mathrm{p}<0.005$; $\log _{10}$-transformed density) (Fig. 3). There was a geometric mean density of 94.6 fish per $400 \mathrm{~m}^{2}$ at BMR sites and 54.4 fish per $400 \mathrm{~m}^{2}$ at NR sites, a relative difference in density (RDD) of 0.27 . A linear regression of total density against position is highly significant $\left(\mathrm{r}^{2}=\right.$ $0.44, F=14.02, \mathrm{df}=1,18, \mathrm{p}<0.005)$, although the ANOVA (i.e. a step-function split at the reserve boundary) explains a similar amount of the between-site vari-

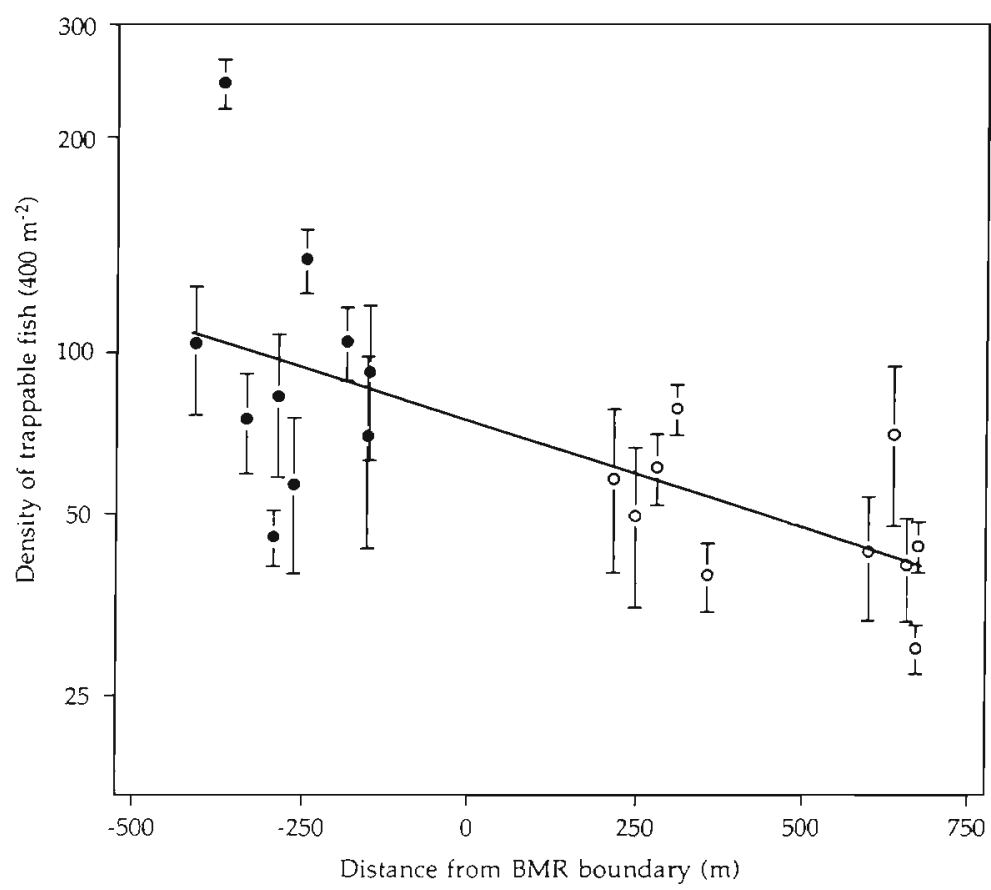

Fig. 3. Total density $\left( \pm \mathrm{SD}\right.$ ) of trappable fish (per $400 \mathrm{~m}^{2}$ ) as a function of distance from the northern BMR boundary. (-) BMR sites; (O) NR sites. Note the $\log _{10^{-}}$scale of the ordinate axis ance $\left(r^{2}=0.38\right)$. There was no significant linear relationship between density and position within the BMR $\left(\mathrm{r}^{2}=0.08, F=0.69, \mathrm{df}=1,8\right.$, not significant [ns] $)$ or within the NR $\left(\mathrm{r}^{2}=0.23, F=2.43, \mathrm{df}=1,8, \mathrm{~ns}\right)$. The total density of non-trappable fish ( $\geq 5 \mathrm{~cm} \mathrm{FL}$ ) did not differ between BMR and NR sites $\left(\mathrm{r}^{2}=0.00, F=0.07, \mathrm{df}=1\right.$, 18 , ns)

Of the 26 species counted in both the BMR and NR, trappable fish from 24 species had a higher mean density at reserve sites (sign test, $p<0.001$ ); however, the difference in density between BMR and NR sites was statistically significant for only 1 species (Scarus iserti; Wilcoxon test, Bonferroni-adjusted $\alpha=0.002$; Table 1). RDD of individual species ranged from -0.10 (Myripristis jacobus) to 0.89 (Kyphosus sectatrix). Non-trappable fish from 20 species were counted: 10 species had a higher mean density of non-trappable fish at BMR sites and 10 species had a higher mean density of non-trappable fish at NR (sign test, ns). Five species (Acanthurus bahianus, A. coeruleus, Haemulon chrysargyreum, H. flavolineatum, and Microspathodon chrysurus) accounted for $77 \%$ of the total visual census density of trappable fish.

The size (FL) of trappable fish was slightly but significantly higher at BMR sites than at NR sites (ANOVA, $\mathrm{r}^{2}=0.05, F=244, \mathrm{df}=1,4852, \mathrm{p}<0.0001$ ). Mean FL was $15.3 \mathrm{~cm}$ in the BMR and $13.8 \mathrm{~cm}$ in the NR, a relative difference in size (RDS) of 0.05 . There was a significant negative correlation between the mean $\mathrm{FL}$ at a site and its position relative to the BMR boundary $\left(\mathrm{r}^{2}=0.64, F=32.2, \mathrm{df}=\right.$ $1,18, p<0.0001$; Fig. 4) although a stepfunction explained as much of the amongsite variance in mean FL (ANOVA, $\mathrm{r}^{2}=$ 0.63, $F=30.8, \mathrm{df}=1,18, \mathrm{p}<0.0001)$. There was no significant effect of position on mean FL within the BMR $\left(\mathrm{r}^{2}=0.07, F=\right.$ 0.59, $\mathrm{df}=1,8, \mathrm{~ns})$ or within the NR $\left(\mathrm{r}^{2}=\right.$ $0.14, F=1.26, \mathrm{df}=1,8, \mathrm{~ns})$.

Twenty-three of 26 species had a greater mean FL at BMR sites than at NR sites (sign test, $p<0.001$ ) and the difference in FL between BMR and NR was significant for 5 species: Acanthurus bahianus, Microspathodon chrysurus, Mulloidichthys martinicus, Scarus taeniopterus, and Sparisoma viride (Wilcoxon test, Bonferroni-adjusted $\alpha=0.002$; Table 2). RDS of species ranged from -0.16 (Caranx ruber, $\mathrm{n}=31$ ) to 0.14 (Epinephelus cruentatus, $\mathrm{n}=27$ ). E. cruentatus, $E$. fulvus, Kyphosus sectatrix, large Scarus and Sparisoma spp., and Lutjanus mahogani exhibited the largest relative differences in size between BMR and NR sites (Fig. 5). 
Table 1. Mean density of species in visual census surveys in the BMR and the NR. $n=$ total sample size in the BMR and NR. $\mathrm{RDD}=\left(\right.$ density $_{\mathrm{BMR}}-$ density $\left._{\mathrm{NR}}\right) /\left(\right.$ density $_{\mathrm{BMR}}+$ density $\left._{\mathrm{NR}}\right) ; \mathrm{Z}$ : Wilcoxon test statistic, p: Wilcoxon test probability

\begin{tabular}{|c|c|c|c|c|c|c|}
\hline Species & $\mathrm{n}$ & $\begin{array}{c}\text { BMR density } \\
\left(400 \mathrm{~m}^{-2}\right)\end{array}$ & $\begin{array}{l}\text { NR density } \\
\left(400 \mathrm{~m}^{-2}\right)\end{array}$ & $\mathrm{RDD}$ & $Z$ & $\mathrm{p}$ \\
\hline Abudefduf saxatilis & 26 & 0.77 & 0.10 & 0.77 & 1.97 & 0.0492 \\
\hline Acanthurus bahianus & 1130 & 22.60 & 1.5 .07 & 0.20 & 1.21 & 0.2261 \\
\hline A. coeruleus & 272 & 6.80 & 2.27 & 0.50 & 3.03 & 0.0025 \\
\hline Bodianus rufus & 17 & 0.37 & 0.20 & 0.29 & 0.85 & 0.3937 \\
\hline Cantherhines pullus & 45 & 0.97 & 0.53 & 0.29 & 0.78 & 0.4377 \\
\hline Caranx ruber & 31 & 0.87 & 0.17 & 0.68 & 1.54 & 0.1231 \\
\hline Chaetodon striatus & 28 & 0.60 & 0.33 & 0.29 & 0.37 & 0.7146 \\
\hline Epinephelus cruentatus & 27 & 0.63 & 0.27 & 0.41 & 2.00 & 0.0454 \\
\hline E. fulvus & 48 & 0.97 & 0.63 & 0.21 & 0.31 & 0.7559 \\
\hline Haemulon carbonarium & 36 & 1.00 & 0.20 & 0.67 & 1.85 & 0.0638 \\
\hline H. chrysargyteum & 548 & 15.60 & 2.67 & 0.71 & 1.39 & 0.1641 \\
\hline H. flavolineatum & 986 & 23.17 & 9.70 & 0.41 & 1.32 & 0.1854 \\
\hline Holocanthus tricolor & 27 & 0.57 & 0.33 & 0.26 & 0.83 & 0.4076 \\
\hline Holocentrus rufus & 70 & 1.53 & 0.80 & 0.31 & 0.88 & 0.3783 \\
\hline Kyphosus sectatrix & 19 & 0.60 & 0.03 & 0.89 & 2.40 & 0.0164 \\
\hline Lactophrys triqueter & 20 & 0.37 & 0.30 & 0.10 & 0.24 & 0.8102 \\
\hline Lutjanus mahogani & 92 & 2.07 & 1.00 & 0.35 & 1.77 & 0.0772 \\
\hline Microspathodon chrysurus & 801 & 13.20 & 13.50 & -0.01 & -0.08 & 0.9397 \\
\hline Mulloidichthys martinicus & 190 & 4.77 & 1.57 & 0.51 & 2.50 & 0.0124 \\
\hline Myripristis jacobus & 168 & 2.53 & 3.07 & -0.10 & -0.99 & 0.3223 \\
\hline Scarus iserti & 77 & 2.37 & 0.20 & 0.84 & 3.49 & 0.0005 \\
\hline S. taeniopterus & 75 & 1.43 & 1.07 & 0.15 & 0.15 & 0.8789 \\
\hline S. vetula & 30 & 0.83 & 0.17 & 0.67 & 1.80 & 0.0717 \\
\hline Sparisoma aurofrenatum & 58 & 1.07 & 0.87 & 0.10 & 0.31 & 0.7569 \\
\hline S. rubripinne & 16 & 0.43 & 0.10 & 0.62 & 2.05 & 0.0408 \\
\hline$S$ viride & 62 & 1.20 & 0.87 & 0.16 & 0.62 & 0.5382 \\
\hline
\end{tabular}

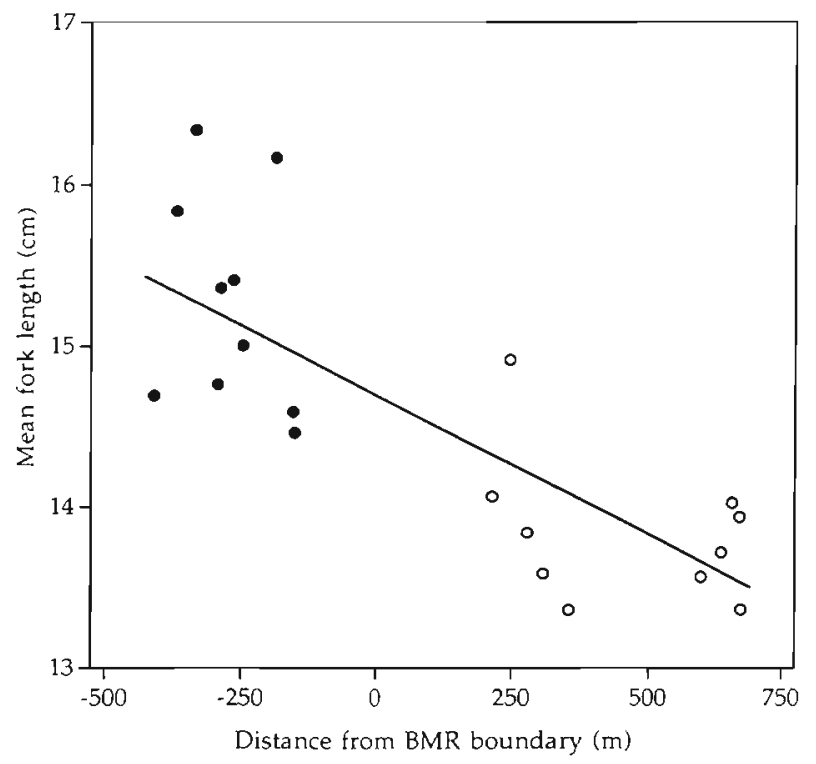

Fig. 4. Mean estimated fork length of trappable fish $(\mathrm{cm})$ as a function of distance from the northern BMR boundary.

(•) BMR sites; (O) NR sites

\section{Habitat correlates of fish density}

There was no significant difference in site depth, rugosity, live coral cover, algal cover, percent sand, percent reef, or percent rubble between BMR and NR study sites (ANOVAs, df $=1,18, p \geq 0.16$ ); however, there were non-significant trends towards greater depth, rugosity, and live coral cover at BMR sites. The 5 most rugose sites, the 4 deepest sites, and the 3 sites with the highest coral cover were in the BMR. Percent rubble and percent reef were slightly, but not significantly, lower at BMR sites than at NR sites.

Deeper sites and sites with greater proportion of reef and rubble substrate had higher total densities of trappable fish. Multiple linear regression of total visual census density against all measured habitat variables showed a significant negative effect of percent sand $(F=10.28, \mathrm{p}<0.01)$ and a positive effect of site depth $(F=6.77, \mathrm{p}<0.05)$ on $\log _{10}$-transformed visual census density (whole model: $\mathrm{r}^{2}=0.41, F=5.79$, df $=2,17, \mathrm{p}<$ $0.05)$.

There was a significant relationship between the visual census density of 18 of 26 species and 1 or more habitat variables (Table 3 ). Table 4 lists the predicted 
Table 2. Fork length of species in visual census surveys in the BMR and the NR. $\mathrm{n}=$ total sample size in both BMR and NR. FLMAx values are from Humann (1994), $\mathrm{RDS}=$ (mean $\mathrm{FL}_{\mathrm{BMR}}$ - mean $\mathrm{FL}_{\mathrm{NR}}$ )/FL $\mathrm{FAX}, Z$ : Wilocoxon test statistic, p: Wilcoxon test probability

\begin{tabular}{|c|c|c|c|c|c|c|c|}
\hline Species & $n$ & $\begin{array}{c}\text { Mean FL } L_{B M R} \\
(\mathrm{~cm})\end{array}$ & $\begin{array}{c}\text { Mean FL } \\
\text { (cm) }\end{array}$ & $\begin{array}{l}F L_{\operatorname{MAX}} \\
(\mathrm{cm})\end{array}$ & RDS & $Z$ & $\mathrm{p}$ \\
\hline Abudefduf saxatilis & 26 & 12.0 & 11.3 & 18 & 0.04 & 0.74 & 0.4571 \\
\hline Acanthurus bahianus & 1130 & 14.4 & 13.1 & 38 & 0.03 & 12.84 & 0.0000 \\
\hline A. coeruleus & 272 & 12.5 & 12.4 & 38 & 0.00 & 0.46 & 0.6477 \\
\hline Bodianus rufus & 17 & 21.2 & 21.2 & 76 & 0.00 & 0.36 & 0.7226 \\
\hline Cantherhines pullus & 45 & 16.2 & 14.8 & 22 & 0.07 & 2.02 & 0.0436 \\
\hline Caranx ruber & 31 & 19.3 & 28.8 & 61 & -0.16 & -1.64 & 0.1003 \\
\hline Chaetodon striatus & 26 & 12.7 & 11.7 & 15 & 0.07 & 1.93 & 0.0503 \\
\hline Epinephelus cruentatus & 27 & 23.3 & 19.1 & 30 & 0.14 & 1.20 & 0.2287 \\
\hline E. fulvus & 50 & 21.8 & 18.3 & 41 & 0.09 & 1.16 & 0.2466 \\
\hline Haemulon carbonarium & 36 & 24.0 & 21.2 & 38 & 0.08 & 1.48 & 0.1395 \\
\hline H. chrysargyreum & 548 & 16.0 & 15.7 & 25 & 0.01 & 2.47 & 0.0134 \\
\hline H. flavolineatum & 986 & 14.4 & 14.2 & 30 & 0.01 & 1.98 & 0.0479 \\
\hline Holocanthus tricolor & 27 & 13.6 & 13.2 & 31 & 0.01 & 0.77 & 0.4431 \\
\hline Holocentrus rufus & 67 & 17.4 & 17.7 & 32 & -0.01 & -0.12 & 0.9054 \\
\hline Kyphosus sectatrix & 19 & 21.8 & 13.0 & 76 & 0.12 & 1.66 & 0.0974 \\
\hline Lactophrys triqueter & 20 & 14.5 & 12.8 & 30 & 0.06 & 0.19 & 0.8473 \\
\hline Lutjanus mahogani & 92 & 20.1 & 17.1 & 38 & 0.08 & 1.58 & 0.1151 \\
\hline Microspathodon chrysurus & 813 & 13.2 & 12.2 & 19 & 0.05 & 8.59 & 0.0000 \\
\hline Mulloidichthys martinicus & 116 & 20.5 & 18.3 & 39 & 0.06 & 3.15 & 0.0016 \\
\hline Myripristis jacobus & 167 & 14.3 & 13.8 & 22 & 0.02 & 2.76 & 0.0058 \\
\hline Scarus iserti & 76 & 17.6 & 15.3 & 28 & 0.08 & 2.90 & 0.0037 \\
\hline S. taeniopterus & 76 & 19.2 & 16.5 & 33 & 0.08 & 4.83 & 0.0000 \\
\hline S. vetula & 30 & 23.3 & 18.3 & 61 & 0.08 & 2.33 & 0.0197 \\
\hline Sparisoma aurofrenatum & 49 & 17.3 & 15.6 & 28 & 0.06 & 2.96 & 0.0031 \\
\hline S. rubripinne & 16 & 25.2 & 26.3 & 46 & -0.02 & -0.82 & 0.4144 \\
\hline S. viride & 64 & 20.7 & 15.9 & 61 & 0.08 & 3.09 & 0.0020 \\
\hline
\end{tabular}

Table 3. Multiple regression models of $\log _{10}$-transformed visual census density against measured habitat variables for the 18 species that a significant relationship with 1 or more habitat variables. Adjusted $\alpha$ : significance level according to the sequential Bonferroni procedure (Rice 1989). ' Significant at adjusted $\alpha_{;}$ns: not significant at adjusted $\alpha$.

\begin{tabular}{|c|c|c|c|c|c|c|c|c|c|c|}
\hline \multirow[t]{2}{*}{ Species } & \multicolumn{3}{|c|}{ Model fit } & \multicolumn{7}{|c|}{ Model coefficients } \\
\hline & $r^{2}$ & p & $\begin{array}{c}\text { Adjusted } \\
\alpha\end{array}$ & Intercept & Depth & Rugosity & $\begin{array}{l}\text { Coral } \\
\text { cover }\end{array}$ & $\begin{array}{c}\text { Percent } \\
\text { sand }\end{array}$ & $\begin{array}{l}\text { Percent } \\
\text { rubble }\end{array}$ & $\begin{array}{c}\text { Percent } \\
\text { reef }\end{array}$ \\
\hline Acanthurus bahianus & 0.56 & 0.0038 & $0.0033 \mathrm{~ns}$ & -2.267 & & 2.078 & & 1.591 & 3.575 & \\
\hline A. coeruleus & 0.41 & 0.0325 & $-n s$ & -4.094 & & 3.153 & & 1.434 & 3.692 & \\
\hline Cantherhines pullus & 0.31 & 0.0116 & - ns & 0.075 & & & & & 1.270 & \\
\hline Epinephelus cruentatus & 0.47 & 0.0145 & ns & -1.390 & & 1.216 & -0.530 & 0.499 & & \\
\hline E. fulvus & 0.27 & 0.0201 & - ns & 0.087 & & & & & 1.224 & \\
\hline Haemulon carbonarium & 0.59 & 0.0005 & 0.0021 & -2.031 & 0.152 & 1.201 & & & & \\
\hline H. chrysargyreum & 0.58 & 0.0006 & 0.0023 & -6.922 & 0.206 & 5.312 & & & & \\
\hline Holocanthus tricolor & 0.55 & 0.0012 & 0.0025 . & -0.242 & 0.060 & & & & 0.870 & \\
\hline Holocentrus rufus & 0.62 & 0.0000 & $0.0019^{\circ}$ & -2.121 & & 1.984 & & & & \\
\hline Lactophrys triqueter & 0.40 & 0.0026 & 0.0031 & 0.027 & & & & & 0.850 & \\
\hline Microspathodon chrysurus & 0.63 & 0.0002 & 0.0020 & 0.524 & & & 0.751 & & & 0.742 \\
\hline Mulloidichthys martinicus & 0.28 & 0.0446 & $-n \mathrm{~ns}$ & -3.582 & 0.204 & 2.4 .54 & & & & \\
\hline Myripristis jacobus & 0.50 & 0.0025 & $0.0029 \cdot$ & -0.083 & 0.206 & & & -1.257 & & \\
\hline Scarus iserti & 0.61 & 0.0014 & 0.0028 & -4.944 & & 3.630 & & 1.370 & 3.112 & \\
\hline S. taeniopterus & 0.55 & 0.0012 & 0.0026 & -0.429 & 0.128 & & & & 0.979 & \\
\hline S. vetula & 0.49 & 0.0006 & 0.0024 & -1.427 & & 1.296 & & & & \\
\hline Sparisoma aurofrenatum & 0.31 & 0.0108 & - ns & 0.090 & & & & & 1.488 & \\
\hline S. viride & 0.59 & 0.0005 & $00022^{*}$ & -0.895 & & 0.783 & 0.965 & & & \\
\hline
\end{tabular}


Table 4. Predicted density in the BMR and NR for the 18 species listed in Table 3 after correcting for habitat correlates of density.

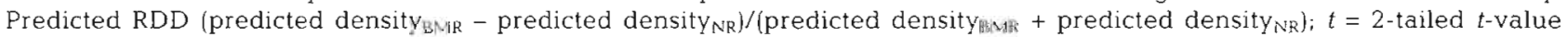
$(\mathrm{df}=18), \mathrm{p}=t$-test probability

\begin{tabular}{|c|c|c|c|c|c|}
\hline Species & $\begin{array}{c}\text { Predicted BMR } \\
\text { density (per } 400 \mathrm{~m}^{2} \text { ) }\end{array}$ & $\begin{array}{c}\text { Predicted NR } \\
\text { density (per } 400 \mathrm{~m}^{2} \text { ) }\end{array}$ & $\begin{array}{l}\text { Predicted } \\
\text { RDD }\end{array}$ & $t$ & $p$ \\
\hline Abudefduf saxatilis & - & - & - & - & - \\
\hline Acanthurus bahianus & 13.26 & 13.49 & -0.01 & 0.09 & 0.93 \\
\hline A. coeruleus & 3.43 & 1.75 & 0.32 & 1.89 & 0.08 \\
\hline Bodianus rufus & - & - & - & - & - \\
\hline Cantherhines pullus & 0.65 & 0.36 & 0.28 & 1.15 & 0.27 \\
\hline Caranx ruber & - & - & - & - & - \\
\hline Chaetodon striatus & - & - & - & - & - \\
\hline Epinephelus cruentatus & 0.47 & 0.32 & 0.18 & 1.16 & 0.26 \\
\hline E. fulvus & 0.62 & 0.44 & 0.17 & 0.64 & 0.53 \\
\hline Haemulon carbonarium & 0.54 & 0.34 & 0.23 & 1.13 & 0.27 \\
\hline H. chrysargyreum & 2.06 & 1.98 & 0.02 & 0.06 & 0.95 \\
\hline H. flavolineatum & - & - & - & - & - \\
\hline Holocanthus tricolor & 0.39 & 0.26 & 0.19 & 0.96 & 0.35 \\
\hline Holocentrus rufus & 0.89 & 0.84 & 0.03 & 0.16 & 0.87 \\
\hline Kyphosus sectatrix & - & - & - & - & - \\
\hline Lactophrys triqueter & 0.27 & 0.22 & 0.11 & 0.45 & 0.66 \\
\hline Lutjanus mahogani & - & - & - & - & - \\
\hline Microspathodon chrysurus & 12.14 & 12.08 & 0.00 & 0.04 & 0.97 \\
\hline Mulloidichthys martinicus & 1.94 & 0.86 & 0.39 & 1.26 & 0.22 \\
\hline Myripristis jacobus & 1.42 & 2.19 & -0.21 & 1.13 & 0.28 \\
\hline Scarus iserti & 0.86 & 0.34 & 0.43 & 2.01 & 0.06 \\
\hline S. taeniopterus & 0.82 & 0.93 & -0.06 & 0.37 & 0.72 \\
\hline S. vetula & 0.49 & 0.25 & 0.33 & 1.45 & 0.16 \\
\hline Sparisoma aurofrenatum & 0.67 & 0.56 & 0.09 & 0.33 & 0.74 \\
\hline S. rubripinne & - & - & - & - & - \\
\hline S. viride & 0.77 & 0.96 & -0.11 & 0.82 & 0.42 \\
\hline Total $^{d}$ & 70.53 & 49.81 & 0.17 & 2.34 & 0.03 \\
\hline
\end{tabular}

BMR and NR densities of these 18 species after controlling for all measured habitat values. After controlling for habitat correlates of fish density, 14 of 18 species have a higher predicted density in the BMR (sign test, $p<0.05$ ), but there is no significant effect of reserve status on fish density for any of the 18 species individually (Wilcoxon test, Bonferroni-adjusted $\alpha=$ 0.0027 : Table 4). The predicted RDD of these species ranges from -0.21 to 0.43 (Table 4). All 8 species for which there was no significant relationship between

Fig. 5. The relative difference in size (estimated fork length, $\mathrm{cm}$ ) between the BMR and NR for 26 species. $(*)$ Significant difference in size between the BMR and NR (Wilcoxon test, sequential Bonferroni-adjusted $\alpha$; sample sizes are given in Table 2)

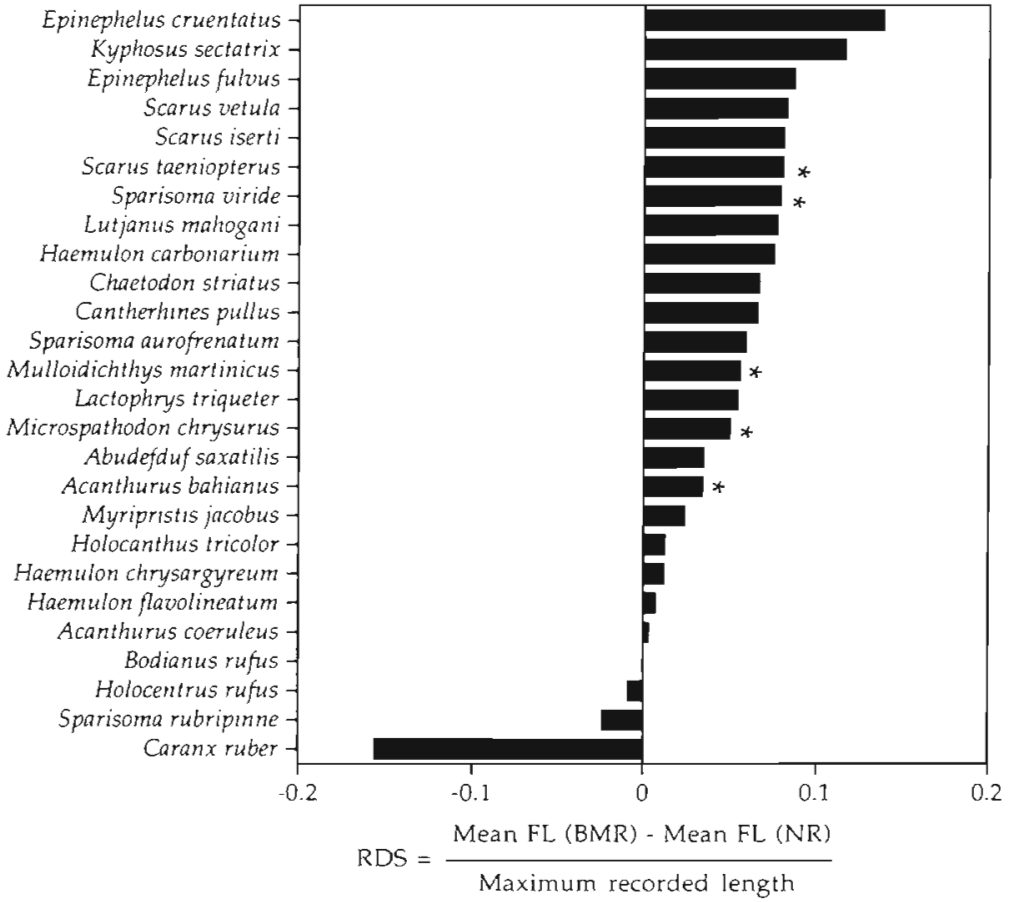




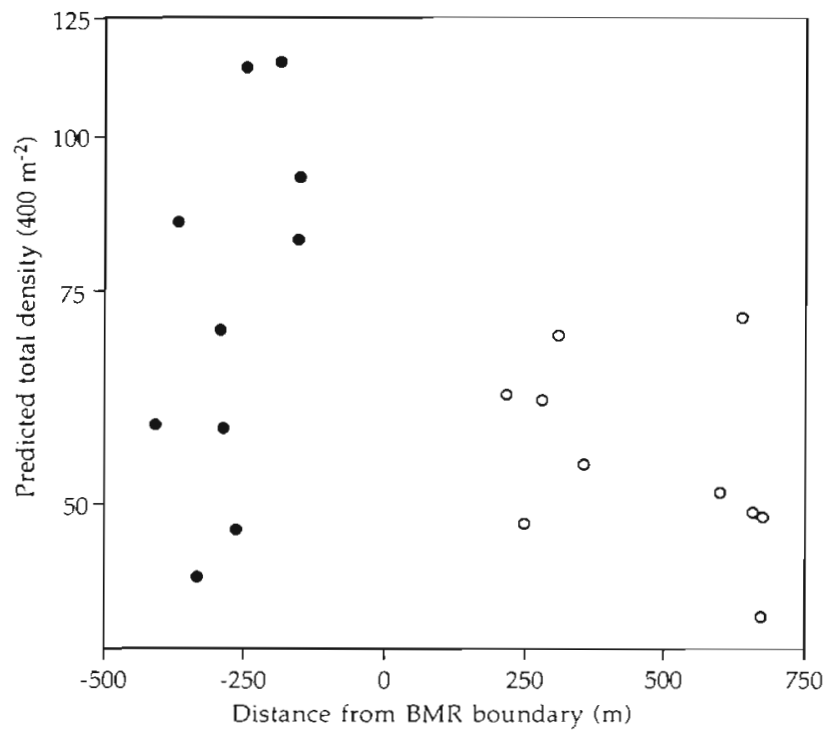

Fig. 6. Predicted fish density (per $400 \mathrm{~m}^{2}$ ) at each site as a function of distance from the northern BMR boundary (after controlling for habitat correlates of species density). ( BMR sites; (O) NR sites

visual census density and any habitat variable had a non-significantly higher density at BMR sites than at NR sites (Table 1). Thus, after correcting for habitat correlates of fish density, 22 of 26 species have a nonsignificantly higher density in the BMR (sign test, $p<$ $0.001)$.

After controlling for the effects of all habitat variables on fish density, the predicted total BMR density is
70.5 trappable fish per $400 \mathrm{~m}^{2}$ and the predicted total NR density is 49.8 trappable fish per $400 \mathrm{~m}^{2}$, giving a predicted RDD of 0.17 (Table 4). The total predicted density is significantly higher for $B M R$ sites than for NR sites $\left(r^{2}=0.23, t=2.34, d f=1,18, p<0.05\right)$ but is not significantly correlated with position relative to the BMR boundary $\left(\mathrm{r}^{2}=0.20\right.$, $\mathrm{df}=1,18, \mathrm{p}<0.10$; Fig. 6) The variance in fish density among sites was therefore only partially accounted for by measured habitat variables; after statistically controlling for habitat correlates of species density, there is a significant effect of reserve status on total fish density.

\section{Habitat correlates of fish size}

There was a significant linear relationship between mean FL at a site and 1 or more habitat variables for 14 of 26 species (Table 5). After controlling for habitat correlates of size, there was no significant effect of reserve status on residual variation in size for any of these 14 species (Wilcoxon test, Bonferroni adjusted $\alpha=$ 0.0036 ). Table 6 lists the predicted mean FL for all BMR sites and all NR sites after controlling for habitat correlates of fish size. Eleven of 14 species have a higher predicted mean FL at BMR sites (sign test, $p<0.05$ ), although the differences are slight. The corresponding predicted RDS for these 14 species ranges from -0.02 (Chaetodon striatus and Sparisoma rubripinne) to 0.17 (Epinephelus cruentatus). Of the 12 species for which there were no significant relationships between mean FL and any habitat variable, 10 species had a non-

Table 5. Multiple regression models of mean FL $(\mathrm{cm})$ against measured habitat variables for the 14 species that have a significant relationship with 1 or more habitat variables. Adjusted $\alpha$ : significance level according to the sequential Bonferroni procedure (Rice 1989). "Significant at adjusted $\alpha$, ns: not significant at adjusted $\alpha$

\begin{tabular}{|c|c|c|c|c|c|c|c|c|c|c|c|c|}
\hline \multirow[t]{2}{*}{ Species } & \multicolumn{3}{|c|}{ Model fit } & \multicolumn{9}{|c|}{ Model coefficients } \\
\hline & $\mathrm{r}^{2}$ & df & $p$ & $\begin{array}{c}\text { Adjusted } \\
\alpha\end{array}$ & $\begin{array}{l}\text { Inter- } \\
\text { cept }\end{array}$ & Depth & $\begin{array}{l}\text { Rugo- } \\
\text { sity }\end{array}$ & $\begin{array}{l}\text { Algal } \\
\text { cover }\end{array}$ & $\begin{array}{l}\text { Coral } \\
\text { cover }\end{array}$ & $\begin{array}{l}\text { Per- } \\
\text { cent } \\
\text { sand }\end{array}$ & $\begin{array}{c}\text { Per- } \\
\text { cent } \\
\text { rubble }\end{array}$ & $\begin{array}{l}\text { Per- } \\
\text { cent } \\
\text { reef }\end{array}$ \\
\hline Acanthurus bahianus & 0.49 & 3,16 & 0.0111 & ns & -0.240 & & 9.636 & & & 4.268 & 7.450 & \\
\hline Chaetodon striatus & 0.65 & 2,7 & 0.0256 & - ns & 9.249 & & & & 6.344 & & 9.010 & \\
\hline Epinephelus cruentatus & 0.50 & 1,13 & 0.0031 & $0.0026 \mathrm{~ns}$ & 12.124 & & & & & 22.327 & & \\
\hline Haemulon chrysargyreum & 0.66 & 1,11 & 0.0008 & 0.0022 & 14.566 & 0.296 & & & & & & \\
\hline H. flavolineatum & 0.64 & 3,16 & 0.0008 & $0.0023^{\circ}$ & 5.795 & & 5.492 & & & 3.413 & 8.267 & \\
\hline Lutjanus mahogani & 0.91 & 1,13 & 0.0000 & 0.0019 & 6.402 & 2.772 & & & & & & \\
\hline Microspathodon chrysurus & 0.53 & 3,16 & 0.0065 & - ns & 5.311 & & 7.406 & 2.840 & & & & -4.969 \\
\hline Mulloidichthys martinicus & 0.46 & 1,9 & 0.0211 & - ns & 30.313 & & -9.576 & & & & & \\
\hline Myripristis jacobus & 0.55 & 1,14 & 0.0010 & 0.0024 & 13.213 & & & & & & 5.537 & \\
\hline Scarus iserti & 0.68 & 2,10 & 0.0031 & - ns & 5.069 & & 14.540 & & & & & -11.145 \\
\hline S. taeniopterus & 0.73 & 2,13 & 0.0002 & $0.0020^{*}$ & -28.277 & & 45.430 & & & & & -15.159 \\
\hline S. vetula & 0.84 & 2,7 & 0.0017 & 0.0025 & -23.715 & & 39.132 & & -19.596 & & & \\
\hline Sparisoma rubripinne & 0.71 & 1,5 & 0.01 .79 & $-\mathrm{ns}$ & 33.367 & -1.591 & & & & & & \\
\hline S. viride & 0.66 & 2,14 & 0.0005 & 0.0021 & -47.656 & & 64.589 & & & & & -24.644 \\
\hline
\end{tabular}


Table 6. Predicted mean FL $(\mathrm{cm})$ in the BMR and NR for the 14 species listed in Table 5 after correcting for habitat correlates of mean FL. Predicted RDS = (predicted $F_{L_{B M R}}$ - predicted $\left.F_{N R}\right) /($ maximum FL); $t: 2$-tailed $t$-value, df: error degrees of freedom, p: $t$-test probability. No species is significantly longer according to the sequential Bonferroni procedure (adjusted $\alpha$ for Epinephelus cruentatus $=0.004$ )

\begin{tabular}{|c|c|c|c|c|c|c|c|}
\hline Species & $\begin{array}{c}\text { Predicted } \\
\text { BMR mean } \\
\text { FL }(\mathrm{cm})\end{array}$ & $\begin{array}{c}\text { Predicted } \\
\text { NR mean } \\
\text { FL }(\mathrm{cm})\end{array}$ & $\begin{array}{c}\operatorname{Max} F L \\
(\mathrm{~cm})\end{array}$ & $\begin{array}{l}\text { Predicted } \\
\text { RDS }\end{array}$ & $t$ & $\mathrm{df}$ & $\mathrm{p}$ \\
\hline Acanthurus bahianus & 13.8 & 13.4 & 38 & 0.01 & 2.13 & 18 & 0.048 \\
\hline Chaetodon striatus & 11.3 & 11.6 & 15 & -0.02 & 0.58 & 8 & 0.576 \\
\hline Epinephelus cruentatus & 22.7 & 17.6 & 30 & 0.17 & 2.51 & 13 & 0.026 \\
\hline Haemulon chrysargyreum & 16.0 & 16.0 & 25 & 0.00 & 0.15 & 11 & 0.880 \\
\hline H. flavolineatum & 14.4 & 14.4 & 30 & 0.00 & 0.09 & 18 & 0.932 \\
\hline Lutjanus mahogani & 20.0 & 19.8 & 38 & 0.01 & 1.25 & 12 & 0.234 \\
\hline Microspathodon chrysurus & 12.9 & 12.6 & 19 & 0.01 & 1.55 & 18 & 0.139 \\
\hline Mulloidichthys martinicus & 18.9 & 18.4 & 39 & 0.01 & 0.53 & 9 & 0.606 \\
\hline Myripristis jacobus & 13.7 & 13.6 & 22 & 0.00 & 0.36 & 14 & 0.728 \\
\hline Scarus iserti & 16.8 & 17.0 & 28 & -0.01 & 0.34 & 11 & 0.743 \\
\hline S. taeniopterus & 19.0 & 18.3 & 33 & 0.02 & 1.14 & 14 & 0.275 \\
\hline S. vetula & 19.2 & 18.5 & 61 & 0.01 & 1.01 & 8 & 0.343 \\
\hline Sparisoma rubripinne & 25.5 & 26.3 & 46 & -0.02 & 0.43 & 5 & 0.687 \\
\hline S. viride & 17.6 & 17.2 & 61 & 0.01 & 0.36 & 15 & 0.722 \\
\hline
\end{tabular}

significantly higher mean fork length at BMR sites (Table 2). Thus, after correcting for habitat correlates of fish size, 21 of 26 species have a greater mean FL at BMR sites than at NR sites (sign test, $\mathrm{p}<0.001$ ).

\section{Fish mobility}

Neither measure of the effect of the reserve on the density or size of species was significantly correlated with either measure of species mobility (Spearman correlations; $\mathrm{RDD}$ and resighting-based mobility: $\mathrm{r}=0.17$, $\mathrm{p}=0.57, \mathrm{n}=13 ; \mathrm{RDD}$ and trap-based mobility: $\mathrm{r}=$ $-0.10, \mathrm{p}=0.74, \mathrm{n}=12 ; \mathrm{RDS}$ and resighting-based mobility: $\mathrm{r}=-0.20, \mathrm{p}=0.51, \mathrm{n}=13$; RDS and trap-based mobility: $r=-0.01, p=0.97, n=12$ ). Thus, our prediction that less mobile species would exhibit a greater difference in density and size between the BMR and NR was not supported.

\section{Vulnerability to fishing gear}

Estimates of the trappability of species ranged from 0.02 (Mulloidichthys martinicus) to 4.69 (Chaetodon striatus) (Table 7). The trappability of species was not positively correlated with the relative difference in density or size of species (RDD: $r=0.12, R D S: r=0.12$, predicted RDD: $r=0.21$, predicted RDS: $r=-0.02 ; p \geq 0.30$ ).

Spearfishing target species had a significantly higher RDS (Wilcoxon $Z=3.34, \mathrm{p}<0.001$ ) and predicted $\operatorname{RDS}(Z=1.99, \mathrm{p}<0.05)$ than non-target species. Individuals longer than $30 \mathrm{~cm}$ FL were recorded in visual census counts in the BMR for all 6 target species, but no individuals of these species longer than $30 \mathrm{~cm}$ FL were recorded in the NR. Spearfishing target species also had a slightly, but not significantly, higher

Table 7 . Trappability in the NR for 24 species of reef fish

\begin{tabular}{|c|c|c|c|}
\hline Species & $\begin{array}{l}\text { Catch } \\
\text { rate (in } \\
10 \text { trap } \\
\text { sets) }\end{array}$ & $\begin{array}{c}\text { Density } \\
(\text { per } \\
\left.4000 \mathrm{~m}^{2}\right)\end{array}$ & $\begin{array}{c}\text { Trappa- } \\
\text { bility }\end{array}$ \\
\hline Abudefduf saxatilis & 1.46 & 1.00 & 1.46 \\
\hline Acanthurus bahianus & 98.61 & 150.67 & 0.65 \\
\hline A. coeruleus & 29.65 & 22.67 & 1.31 \\
\hline Bodianus rufus & 1.44 & 2.00 & 0.72 \\
\hline Cantherhines pullus & 10.23 & 5.33 & 1.92 \\
\hline Chaetodon striatus & 15.62 & 3.33 & 4.69 \\
\hline Epinephelus cruentatus & 0.70 & 2.67 & 0.26 \\
\hline E. fulvus & 2.27 & 6.33 & 0.36 \\
\hline H. chrysargyreum & 3.04 & 26.67 & 0.11 \\
\hline H. flavolineatum & 15.70 & 97.00 & 0.16 \\
\hline Holocanthus tricolor & 1.11 & 3.33 & 0.33 \\
\hline Holocentrus rufus & 0.97 & 7.00 & 0.14 \\
\hline Kyphosus sectatrix & 0.10 & 0.33 & 0.30 \\
\hline Lactophrys triqueter & 0.36 & 3.00 & 0.12 \\
\hline Lutjanus mahogani & 0.69 & 10.00 & 0.07 \\
\hline Microspathodon chrysurus & 20.99 & 139.67 & 0.15 \\
\hline Mulloidichthys martinicus & 0.18 & 8.67 & 0.02 \\
\hline Myripristis jacobus & 8.85 & 30.33 & 0.29 \\
\hline Scarus iserti & 1.59 & 2.00 & 0.80 \\
\hline S. taeniopterus & 2.23 & 11.00 & 0.20 \\
\hline S. vetula & 2.00 & 1.33 & 1.50 \\
\hline Sparisoma aurofrenatum & 4.00 & 7.33 & 0.55 \\
\hline S. rubripinne & 0.34 & 1.00 & 0.34 \\
\hline S. viride & 3.77 & 8.67 & 0.44 \\
\hline
\end{tabular}


$\operatorname{RDD}(Z=0.67, \mathrm{~ns})$ and predicted $\operatorname{RDD}(Z=0.41, \mathrm{~ns})$ than non-target species. Partial rank-order correlation analysis did not reveal any partial correlations between differences in density or size (RDD, RDS, predicted RDD, or predicted RDS) and trappability or mobility (Kendall $T \leq 0.35, \mathrm{p}>0.05$ ).

\section{DISCUSSION}

The visual census data show a slight but consistent effect of reserve status on the distribution and sizestructure of the trappable reef fish assemblage. Without data on the density and size of fishes at sites inside and outside the BMR prior to reserve implementation, we cannot conclude with certainty that differences between BMR and NR sites are due to protection from fishing within the BMR. Although much of the amongsite variance in total fish density could be attributed to differences in habitat characteristics, a significant proportion of the variance in total density between study sites in the BMR and those in the NR could not be explained by measured habitat variables (and is most likely attributable to the presence of the reserve). The density of non-trappable fishes was not higher at BMR sites than at NR sites, and reef fish larval supply is typically lower on BMR reefs than on NR reefs north or south of the BMR (Sponaugle \& Cowen 1996), suggesting that the higher density at our BMR sites is not due to differences in the rate of settlement.

After correcting for habitat correlates of density and size, the predicted relative difference in total density between BMR and NR sites was 0.17. Published values of the relative difference in fish density (RDD) between no-take coral reef marine reserves and adjacent fished areas range from -0.20 to 0.47 (Samoilys 1988, Grigg 1994). Differences among reserves in time since establishment, enforcement and observance of reserve regulations, fish community structure, fishing intensity in the adjacent area, and state of the fish community and reef habitat before reserve establishment, render comparisons of reserves' effects on fish distribution difficult. Nevertheless, the differential in fish density between BMR sites and adjacent NR sites appears typical of coral reet marine reserves elsewhere in the Caribbean and Indo-Pacific (e.g. Grigg 1994). The observed patterns of fish density and size are generally consistent with a previous survey of the BMR and adjacent NR over a broader spatial scale. In a visual census survey of all 5 fringing reefs of the BMR and 8 reefs north and south of the BMR, Rakitin \& Kramer (1996) found a relative difference in fish density between the BMR and NR of 0.26 , with 19 of 24 species having a higher density in the BMR, and 18 of 24 species having a higher mean estimated FL in the BMR.
After correcting for habitat correlates of density and size, 22 of 26 species had a higher density in the BMR, and 21 of 26 species had a greater predicted mean size in the BMR; however, none of the predicted differences in the density or size of individual species between the BMR and NR were statistically significant. Spatial variation in recruitment, survival, competition, and habitat structure all result in high spatial variability in fish density (Williams 1991). The patchy distributions and low densities of many species reduce the accuracy and power of statistical comparisons of individual species over the small spatial scale $(1 \mathrm{~km})$ studied. Several other studies have found significant differences in total fish density and non-significant trends towards higher density, size, or biomass of individual species (e.g. Samoilys 1988, Roberts \& Polunin 1993, Roberts 1994).

\section{Habitat correlates of the density and size of reef fishes}

The density and size distributions of many species of coral reef fish are strongly associated with habitat characteristics (e.g. Luckhurst \& Luckhurst 1978, Bell \& Galzin 1984, Caley \& St. John 1996, Jennings et al. 1996). Although we found no significant difference between the BMR and NR for any measured habitat variable, there were non-significant trends towards greater site depth, rugosity, and percent live coral cover in the BMR. This study demonstrates that the lack of a significant difference in habitat characteristics between reserve and non-reserve sites does not rule out the possibility that differences in fish density or size between the reserve and non-reserve are attributable to habitat differences. Jennings et al. (1996) used multiple regression to identify correlates of reef fish biomass, including fishing pressure as an independent variable along with several habitat characteristics, and found significant effects of fishing pressure and habitat characteristics on the biomass of several species. In order to exclude differences in fish distribution potentially due to habitat variables, where habitat quality is higher in a reserve, we tested the effect of habitat variables on species density, size, or biomass and tested residual variation against reserve status Grigg (1994) used a similar approach, comparing the variance in Hawaiian reef fish biomass explained by habitat complexity alone $(51 \%)$ to the variance explained by a model including effects of habitat complexity, sewage outfalls, and fishing pressure $(60 \%)$. Note, however, that statistically controlling for habitat correlates may attribute effects of reserve protection to spuriously correlated habitat characteristics, increasing the potential for type II error when testing for significant effects of reserve protection. Results indicating 
no significant effect of reserve status based on this approach should therefore be interpreted cautiously.

In general, deep, rugose sites with a high proportion of reef and rubble (as opposed to sand) had high densities of fish. Rugosity was positively correlated with the density of 10 species, and site depth was positively correlated with the density of 6 species. Density was positively correlated with both depth and rugosity for 3 of the 5 study species which form diurnal resting schools; large diurnal resting schools of Haemulon and Mulloidichthys species were often associated with high-relief reef spurs at the seaward edges of fringing reefs.

Percent sand cover was negatively correlated with total fish density, and the density of trappable fishes was generally much lower over sand than over reef and rubble: for example, marked fish were over sand in only 93 of 989 resightings, although sand accounted for $39 \%$ of the area of study sites (Chapman 1997). The density of 4 species, however, was positively correlated with both percent sand and rugosity. In this study, Iugosity was measured across all substrate types. Because rugosity over sand is uniformly low, the multiple correlations of density, percent sand and rugosity may imply that sites with the most rugose reef substrate-i.e. high rugosity despite high percent sand-tend to have a higher density of these species. However, rugosity was negatively correlated with percent sand $(r=-0.73, p<0.001)$ and positively correlated with percent reef $(r=0.84, p<0.001)$, so the biological significance of these multiple regressions should be interpreted with caution (Zar 1996). Of course, positive correlations of density with percent sand or percent rubble may also indicate the importance of reef habitats with adjacent rubble and sand. We suggest that future studies investigating the habitat associations of reef fishes measure habitat quality separately for different substrate types, in order to distinguish between effects of substrate composition and substrate structural characteristics on fish distribution.

The size (mean FL) of many species was also correlated with the habitat characteristics of study sites (Table 5). As with density, increased size was often associated with higher rugosity. Regression models often included both rugosity and percent reef (4 species) or percent sand and rubble (2 species), further suggesting that measurement of habitat complexity in areas of mixed substrate composition should be stratified according to substrate type.

Residual variation in fish density and size among sites may be due to unexamined habitat variables or non-linear relationships between measured habitat variables and density and size. Furthermore, the fixed spatial scale at which density and habitat correlates were assessed $\left(400 \mathrm{~m}^{2}\right)$ is likely to reduce the accuracy of models of habitat correlates of fish density and size, and thus tests of the effect of reserve protection on fish density and size. The potential scale dependence of correlations between species density and habitat characteristics implies that habitat correlates of density should be tested at the spatial scale of the home range of study species (Roberts \& Ormond 1987, Jennings et al. 1996). Detailed studies focusing on the habitat associations of individual species would be required to more accurately assess the effects of habitat characteristics on the distribution and size structure of reef fish.

Higher habitat quality inside reserves may result from siting reserves in areas with abundant fish and high habitat quality. However, reserve establishment may also increase habitat quality by protecting reserve habitat from destructive fishing practices. In the BMR, the prohibition of demersal trapping and boat traffic (and associated anchor damage) may contribute to increased rugosity and coral cover, both of which were correlated with increased density and size of some reef fishes.

\section{Vulnerability to fishing gear}

The density of trappable fish was higher at BMR sites than at NR sites, and there was no difference between the BMR and NR in the density of non-trappable fish ( $\geq 5 \mathrm{~cm}$ estimated FL), suggesting a strong role for the elimination of trap fishing on fish distribution and size. Surprisingly, however, the relative difference in the density or size of species between the BMR and NR was not positively correlated with their trappability. This suggests that the elimination of trap-fishing mortality within the BMR may not be the principal reason for the reserve's effect on fish distribution and size. Little trap fishing was observed on the 2 NR study reefs, and trap fishing appears to be declining in importance as older fishers leave the fishery and are not replaced by younger fishers; the average age of trap fishers in Barbados is over 50 yr (Mahon \& Drayton 1990). Alternatively, differences in the growth rates, settlement, and natural mortality of species may obscure the effects of relative differences in trappability on differences in distribution and size structure between the BMR and NR. Moreover, the patchy distribution of species, as well as reducing the power of tests of reserve effect for individual species, reduces the precision of indices of the reserve's effect on the density of individual species.

There was some evidence that species subject to spearfishing mortality in the NR benefited more from reserve protection: spearfishing target species exhibited a significantly higher relative difference in size than non-target species. This pattern is consistent with 
the size selectivity of spearfishing. Avoidance of divers by large fish in spearfished areas (Bell 1983, Jennings \& Polunin 1995) could possibly account for the observed difference in census-based size distributions between the BMR and NR. However, data from trap catches at all 20 study sites (Chapman 1997) show a significant difference between BMR and NR sites in the size (measured FL) of these 6 species combined (Wilcoxon $Z=2.87, \mathrm{p}<0.005, \mathrm{n}=181$ ), and for $E$. fulvus $(Z=2.74, \mathrm{p}<0.01, \mathrm{n}=33)$ and $S$. vetula $(Z=3.13$, $\mathrm{p}<0.005, \mathrm{n}=30$ ). These data suggest that spearfishing mortality affects the size distribution of target species on NR fringing reefs, and that protection from spearfishing mortality increases the relative abundance of large individuals in the BMR.

\section{Fish movements}

Mark-recapture data suggest that the rate of emigration of post-settlement reef fishes from the BMR is negligible (Chapman \& Kramer in press). Movements between fringing reefs separated by 20 to $300 \mathrm{~m}$ of sand were rare, and this plus the lack of a negative correlation between the mobility of species and their relative difference in density or size of species or RDS imply that post-settlement fish movements do not affect the ability of the BMR to maintain greater fish density and size than the NR. Moreover, the spatial pattern of fish density does not provide support to the hypothesis that emigration affects fish distribution between BMR and NR study reefs. Rakitin \& Kramer (1996) hypothesized that fish were emigrating across the BMR boundaries based on a spatial gradient in trap catch rates. After correcting for habitat correlates of fish density, we did not find a significant correlation between total fish density and position relative to the BMR boundary.

Large expanses of sand between coral reefs appear to inhibit movements of many reef fish species (Hobson 1973, Doherty 1983, Robertson 1988, Roberts \& Polunin 1991), limiting spillover and maintaining differences in density between reserves and adjacent exploited areas (Barrett 1995, Kramer \& Chapman in press). However, the within-reef mobility of many species (at the scale of 10 s to 100 s of metres) suggests that spillover from small coral reef marine reserves could be significant where reserve boundaries intersect more structurally complex habitats (e.g. Appeldoorn et al. 1997, Corless et al. in press).

A growing number of authors have suggested that the primary benefit of marine reserves to coral reef fisheries is their potential for enhancing larval output (Roberts \& Polunin 1991, Russ et al. 1992, Holland et al. 1993, 1996, Sladek Nowlis \& Roberts 1997). Modeling suggests that yield enhancement via spillover from marine reserves will occur only under relatively narrow conditions of fish mobility and fishing mortality, and will be slight compared to potential increases in yield due to larval output (Polacheck 1990, DeMartini 1993, Sladek Nowlis \& Roberts 1997). In order to maximize the increase in density and size - and thus the reproductive output - of fish inside a marine reserve, spillover should be minimized.

Although minimizing spillover may maximize the net benefit of the reserve in terms of the enhancement of fish biomass in the fishery, the ecological and socioeconomic benefits of larval export may be spatially diffuse and temporally variable. Larval export may fail to engender support from local fishers for the continued existence of the marine reserve. By exporting fish biomass directly to the adjacent fishery, spillover may provide local benefits and reduce the local socio-economic costs of reserve implementation (Russ \& Alcala 1989, PDT 1990, Roberts \& Polunin 1991). In many reef fisheries, the provision of harvestable fish biomass to the exploited area immediately adjacent to a reserve may be necessary for the sustenance of the local reef fishery and to ensure political support for the reserve. However, excessive emigration will compromise the ability of the reserve to conserve stocks and to sustain the fishery. Designing coral reef marine reserves that will export fish biomass without compromising the sustainability of exploited stocks requires a richer understanding of the movement patterns of exploited fishes in relation to the distribution of fish and habitats.

Acknowledgements. We thank Dave Robichaud, Dana Haggarty, Ian Popple, Marianne Corless, Julie Bauman, Kelvin Skinner, Tom Bell, Huw Maggs, Maria Patriquin, and the staff of the Bellairs Research Institute for help in the field. Amanda Vincent provided valuable comments on an earlier draft. Special thanks to James Van Loon for help with the analysis of fish movement data. This research was funded by a Commander C.F. Bellairs Fellowship and a Jumpstart Society Award to M.R.C. and by an NSERC research grant to D.L.K.

\section{LITERATURE CITED}

Alleyne S (1996) The severity and aetiology of a mass mortality of reef fish on fringing reefs on the west coast of Barbados in 1994. MSc thesis report, University of the West Indies, Cave Hill

Appeldoorn RS, Recksiek CW, Hill RL, Pagan FE, Dennis GD (1997) Marine protected areas and reef fish movements: the role of habitat in controlling ontogenetic migration. Proc 8th int Coral Reef Symp 2:1917-1922

Barrett NS (1995) Short- and long-term movement patterns of six temperate reef fishes (Families Labridae and Monacanthidae). Mar Freshw Res 46:853-860

Bell JD (1983) Effects of depth and marine reserve fishing restrictions on the structure of a rocky reef fish assemblage in the north-western Mediterranean sea. J Appl Ecol 20:357-369 
Bell JD, Galzin R (1984) Influence of live coral cover on coralreef fish communities. Mar Ecol Prog Ser 15:265-274

Bohnsack JA (1996) Maintenance and recovery of reef fish productivity. In: Polunin NVC, Roberts CM (eds) Reef fisheries. Chapman \& Hall, London, p 283-313

Bohnsack JA, Ault JS (1996) Management strategies to conserve marine biodiversity. Oceanography 9:73-82

Caley JM, St. John J (1996) Refuge availability structures assemblages of tropical reef fishes. J Anim Ecol 65: $414-428$

Chapman MR (1997) Coral reef fish movements and the effectiveness of the Barbados Marine Reserve. MSc thesis, McGill University, Montréal

Chapman MR, Kramer DL (in press) Movement of fishes within and among fringing coral reefs in Barbados. Environ Biol Fish

Corless $M$, Hatcher BG, Hunte W, Scott $S$ (in press) Assessing the potential for fish migration from marine reserves to adjacent fished areas in the Soufrière Marine Management Area, St. Lucia. Proc Gulf Caribb Fish Inst

DeMartini EE (1993) Modeling the potential of fishery reserves for managing Pacific coral reef fishes. Fish Bull 91:414-427

Doherty PJ (1983) Tropical territorial damselfishes: is density limited by aggression or recruitment? Ecology 64:176-190

Dugan JE, Davis GE (1993) Applications of marine refugia to coastal fisheries management. Can J Fish Aquat Sci 50: 2029-2042

Grigg RW (1994) Effects of sewage discharge, fishing pressure and habitat complexity on coral reef ecosystems and reef fishes in Hawaii. Mar Ecol Prog Ser 103:25-34

Hobson ES (1973) Diel feeding migrations in tropical reef fishes. Helgoländer Wiss Meeresunters 24:361-370

Holland KN, Peterson JD, Lowe CG, Wetherbee BM (1993) Movements, distribution and growth rates of the white goatfish Mulloides flavolineatus in a fisheries conservation zone. Bull Mar Sci 52:982-992

Holland KN, Lowe CG, Wetherbee BM (1996) Movements and dispersal patterns of blue trevally (Caranx melampygus) in a fisheries conservation zone. Fish Res 25:279-292

Humann P (1994) Reef fish identification-Florida, Caribbean, Bahamas, 2nd edn. New World Publications, Jacksonville, FL

Jennings S, Polunin NVC (1995) Biased underwater visual census biomass estimates for target species in tropical reef fisheries. J Fish Biol 47:733-736

Jennings S, Boullé DP, Polunin NVC (1996) Habitat correlates of the distribution and biomass of Seychelles reef fishes. Environ Biol Fish 46:15-25

Kramer DL, Chapman MR (in press) Implications of fish home range and relocation for marine reserve function. Environ Biol Fish

Lechowicz MJ (1982) The sampling characteristics of electivity indices. Oecologia 52:22-30

Lewis JB (1960) The coral reefs and coral communities of Barbados, W.I. Can J Zool 38:1133-1145

Luckhurst BE, Luckhurst K (1978) Analysis of the influence of substrate variables on coral reef fish communities. Mar Biol 49:317-323

Mahon R, Drayton N (1990) Trap fishery management in Barbados: the fisherman's perspective. Caribb Mar Stud 1: $94-100$

Matthews KR, Reavis RH (1990) Underwater tagging and visual recapture as a technique for studying movement patterns of rockfish. Am Fish Soc Symp 7:168-172

Miller RJ, Hunte W (1987) Effective area fished by Antillean traps. Bull Mar Sci 40:484-493
Munro JL, Reeson PH, Gaut VC (1971) Dynamic factors affecting the performance of the Antillean fish trap. Proc Gulf Caribb Fish Inst 23:184-194

Plan Development Team (1990) The potential of marine fishery reserves for reef fish management in the U.S. Southern Atlantic. NOAA NMFS Tech Memo NMFS-SEFC-261, NOAA, Washington, DC

Polacheck T (1990) Year round closed areas as a management tool. Nat Res Model 4:327-354

Polunin NVC, Roberts CM (1993) Greater biomass and value of target coral-reef fishes in two small Caribbean marine reserves. Mar Ecol Prog Ser 100:167-176

Rakitin A (1994) The effect of a marine reserve on the abundance and size of coral reef fishes in Barbados, West Indies. MSc thesis, McGill University, Montréal

Rakitin A, Kramer DL (1996) Effect of a marine reserve on the distribution of coral reef fishes in Barbados. Mar Ecol Prog Ser 131:97-113

Rice WR (1989) Analyzing tables of statistical tests. Evolution 43:223-225

Roberts CM (1994) Rapid build-up of fish biomass in a Caribbean marine reserve. Conserv Biol 9:815-826

Roberts CM, Ormond RFG (1987) Habitat complexity and coral reef fish diversity and abundance on Red Sea fringing reefs. Mar Ecol Prog Ser 41:1-8

Roberts CM, Polunin NVC (1991) Are marine reserves effective in management of reef fisheries? Rev Fish Biol Fishes 1;65-91

Roberts CM, Polunin NVC (1993) Marine reserves: simple solutions to managing complex fisheries? Ambio 22: 363-368

Robertson DR (1988) Abundances of surgeonfishes on patchreefs in Caribbean Panamá: due to settlement, or post-settlement events? Mar Biol 97:495-501

Robichaud DR (1996) Factors affecting catch, fishing power and trappability in the Barbados trap fishery. MSc thesis, McGill University, Montréal

Robichaud DR, Hunte W, Oxenford HA (1999) Effects of increased mesh size on catch and fishing power of coral reef fish traps. Fish Res 39:275-294

Rowley RJ (1994) Marine reserves in fishery management. Aquat Conserv Mar Freshw Ecosyst 4:233-254

Russ GR (1985) Effects of protective management on coral reef fishes in the central Philippines. Proc 5th Int Coral Reef Congr 4:219-224

Russ GR, Alcala AC (1989) Effects of intense fishing pressure on an assemblage of coral reef fishes. Mar Ecol Prog Ser 56:13-27

Russ GR, Alcala AC (1996) Marine reserves: rates and patterns of recovery and decline of large predatory fish. Ecol Appl 6:947-961

Russ GR, Alcala AC, Cabanban AS (1992) Marine reserves and fisheries management on coral reefs with preliminary modelling of the effects on yield per recruit. Proc 7 th Int Coral Reef Symp 2:978-985

Samoilys MA (1988) Abundance and species richness of coral reef fish on the Kenyan coast: the effects of protective management and fishing. Proc 6th Int Coral Reef Symp 2: 261-266

Sladek Nowlis J, Roberts CM (1997) You can have your fish and eat it, too: theoretical approaches to marine reserve design. Proc 8th int Coral Reef Symp 2:1907-1910

Sponaugle S, Cowen RK (1996) Nearshore patterns of coral reef fish larval supply to Barbados, West Indies. Mar Ecol Prog Ser 133:13-26

Stearn CW, Scoffin TP, Martindale W (1977) Calcium carbonate budget of a fringing reef on the west coast of Barbados: 
part I - zonation and productivity. Bull Mar Sci 27:479-510 St. Hill YL (1987) The protected areas of Barbados. Report No. 2: Management plan for the Barbados Marine Reserve. Environmental Unit, Ministry of Employment, Labour and Community Development, Bridgetown

Editorial responsibility: Otto Kinne (Editor), Oldendorf/Luhe, Germany
Williams DMcB (1991) Patterns and processes in the distribution of coral reef fishes. In: Sale PF (ed) The ecology of fishes on coral reefs. Academic Press, San Diego, p 437-474

Zar JH (1996) Biostatistical analysis, 3rd edn. Prentice Hall, Upper Saddle River, NJ

Submitted: February 16, 1998; Accepted: November 3, 1998 Proofs received from author(s): May 3, 1999 